'For Time is / nothing if not amenable' — exemplarity, time, reception

Constanze Güthenke

\title{
Amenable time
}

In its ancient expression, exemplarity indicates the use of examples, whether historical, biographical, literary, or stylistic, in often overlapping rhetorical, literary, and moral senses. Prompted by revisiting this mode of reading, with its prevalence in Greek and Roman antiquity and well into the Early Modern period, this essay seeks to understand exemplarity more broadly as a mode of reading the past and, by extension, of reading classical antiquity. Going one step further, I suggest that as a mode of reading antiquity exemplarity might also be able to help us to think through, to consider, and to disrupt readings of antiquity, or modes of reading, familiar to us in the modern period. Those familiar modes have been determined by historicizing and idealizing tendencies alike, and have taken predominantly teleological narrative form: time progresses in a linear fashion, creating effects of continuity or discontinuity with the past. Exemplarity can break through such linear narratives, and it can do so without having to demand normativity, or imply difference-as-loss. Exemplarity is concerned with intelligibility, and it extends an offer of ordering experience. And yet, this awareness of the specificities of place and time, of the exemplar as much as of its recipients, does not fix either of them in place or time. Nor, importantly, is exemplarity predicated on an expectation of perfection, or concerned with a pathology of its lack.

In its essential flexibility, exemplarity is also an invitation to rethink the standing of rhetoric. Rhetoric is not the outer shell of representation, the 'frills' of expression surrounding content, but a mode of thought and of making facts, and thus itself is an attitude to the past and a way of establishing the past. This makes rhetoric a bridge between philology 
— capaciously understood as making sense of texts with close attention to their language and history, and it makes exemplarity, equally, a philological, historical, and ethical practice.

The quotation in my title — in good exemplary fashion — comes from a poem by Elizabeth Bishop, 'The Shampoo' (1955). There may not be much Classics in Bishop, though her own considered amenability, her poise and deflection with regard to traditions, and her strong notions of poetic form arguably constitute a finely crafted engagement with the classical. Still, hers is a poetic reflection on capital-T time: by making time into Time, personified, mythical, and standing out, time itself acquires an exemplary sense.

In the tautly structured poem, the observation of lichen on rocks, spreading in concentric circles that to the poet echo the rings of the moon, lead to a reflection on the changing and unchanging nature of memory, ultimately returning the focus from the heavens back to the concrete caring act of washing the beloved's hair, in a basin that reflects the stars above. The poem's first stanza suggests a cosmic, coherent, natural, but also non-linear rhymed time. This time is not without paradox, with its emphasis on explosion and stillness, on spread and unchangingness, though the latter is subtly modified as an effect of human memory, not necessarily nature. It is a time that rests on arrangement, whether spatial or social: having 'arranged to meet' implies control and concession at the same time. The second stanza turns from 'our' to 'us', and on to the particular, dear 'you', marking a complex temporality: the word 'since' is used causally, but it also exerts an ungrammatical temporal pull, a pull between future, and perfective present ('since the heavens will attend [...] you've been'), addressing a 'you' who, 'precipitate and pragmatical', hurries time along — and Time, half-ironic, half-universal, follows suits (half-rhyming, in a precipitate way, 'amenable' with 'pragmatical'). Embracing time that cannot be stopped, the particular moment and the particular black hair about to be washed offer a counter-point of ebb and 
flow, an extension into universal time in their short-lived moment. Their moment offers an exhortation and an encouragement, and constitutes an acknowledgement that ends in unvarnished simile when the poem comes back, full circle, to the moon's rings. Simile, of course, is always about what is different as much as it is about what is the same, and thus we end with a similarity that, like exemplarity, is at once provisional, situated, deliberate, and also contingent. ${ }^{1}$

Bishop's poem is also a love poem, and in this it is a good reminder about the affective investments at work in exemplarity and in temporality, of singling out examples from the past and putting them in relation to and in the present. It is worth pushing back against an equation of an affective relationship with the past and a desire for fusion with the past. $^{2}$ What is notable about Bishop's tone is the non-nostalgic sense of time (or Time), the scepticism and courteousness alike of the word 'amenable', the abiding remoteness and at the same time the intimate taking ownership of time, and the clear-eyed understanding of its momentous suspension in the writing of poetry. The term 'amenable' suggests compliance, tolerance, playfulness, a moving in concert; but it also suggests rules, ironies, and wishful thinking about bringing time around. It suggests the timely while instantly underscoring the untimely, the kairotic and momentous, as much as the element of decorum with its sense of courtliness, and expectation of exemplary behaviour.

Bishop's poetic reflection on time, and her subtle, well-turned sense of amenability function here in my argument as an 'exemplar' of sorts, as an invitation and an offer of structure to consider the dynamic of exempla. In their ancient jointly rhetorical and moral sense, they can offer a fruitful handle on thinking through our understanding of anachronism as much as of our construction of the temporal relationships with and in antiquity, and it is

\footnotetext{
${ }^{1}$ For the logic of similes and similarity, and especially for the power of poetry to think through and with the simile, see Burt (2014).

${ }^{2}$ I am trying to make such an argument in Güthenke (2020).
} 
the 'amenability' or flexibility, the dynamic between template and choice, between precedent and re-instantiation, which is also a temporal relationship, that I want to highlight with the help of that term.

\section{The logic of exemplarity}

Exemplarity as a rhetorical phenomenon familiar from the Greco-Roman tradition, with active and ethical implications, is a mainstay of Roman rhetoric, but, arguably, falls out of favour in the extended transition zone between the early modern and the modern world. ${ }^{3}$ It does so at the same time as the notion of imitation, making way for predominantly linear, progressive forms and narratives of historicism and historical contextualism, and for a notion of personal transformation as the key to individual subjectivity. In essence, this is what Rainhard Koselleck described as the rise of capital-H History, combined with a predominant discourse of Bildung. ${ }^{4}$ To train the spotlight back on exemplarity, as I attempt to do in this essay, is not to aim at turning back the clock. There is no 'outside' historicism, nor is historicism simply a modern imposed category: this, importantly, is one of the insights that has animated the Anachronism and Antiquity project of which this special issue forms a part. Instead, revisiting exemplarity is to highlight some of its features that not only help to disrupt a sense of progressive — and as its counterpart nostalgic and desiring — time, including the progressive notion of time marking modern disciplines, but that also challenge us to reflect on what reaching across time might mean and imply. In addition, it does so in a way that takes account of our own situatedness at any given time, and the ways in which, in Bishop's terms, 'we arrange to meet' the rings of the moon and our own memories of things ostensibly unchanging. 'Arrangement', again, seems a key term here, a term that suggests selection,

\footnotetext{
${ }^{3}$ For such a 'crisis of exemplarity', see Hampton (1990); the special issue on the 'Crisis of Exemplarity' in the Journal of the History of Ideas 59 (1995).

${ }^{4}$ Koselleck (1967).
} 
agency, and an ongoing process of negotiation, structuring, and concession. In this call for changing the emphasis, and for integrating the reflection of our practices and their histories into the practices themselves, I echo a similar point Simon Goldhill has recently made apropos the case study. ${ }^{5}$ The case study, as a tried and familiar form of thinking and a unit of interpretation in the Humanities (and Social Sciences) will not go away, he argues. Historicist understanding and analysis will not do so either, I would add. But there is a need to extend the notion of exemplarity — as we both argue with respect to our discipline's reliance on case studies, examples, and historical contextualization — to the (self-)situating of the scholar. ${ }^{6}$ The aim is to see more clearly — and reflect more critically — the structures of exemplarity that are inherent in any form of classicism, where they indicate and create both value and narrative genealogies.

In terms of the dynamic of exemplarity, exempla are in the first instance 'parts' of the past. They are events, figures (mythological or historical), and narrative tropes that encourage in their recipients a reaction of praise or blame and that are expected to stimulate the recipient's own actions, thought, and behaviour. It is widely acknowledged (in linguistics, law, science, or history) that 'examples' share a double ontology as particular and as universal, or rather as mediating between the two. They are representative parts of a series with which they share features, but they are also particular and paradigmatic in their difference. Rebecca Langlands has recently articulated very clearly how much the complexity of (Roman) exempla actually rests not only on that double identity of the exemplum being both single and relating to a multiple, but, furthermore, also on the situatedness and 'sitespecificity' of each encounter, thus interrupting an ostensibly strong sense of exempla as norms and precepts awaiting or demanding straightforward imitation. In her words, 'Roman

\footnotetext{
${ }^{5}$ Goldhill (2017).

${ }^{6}$ Goldhill (2017), and The Postclassicisms Collective (2019).
} 
exemplarity offered a simultaneous display of a wide variety of exemplary tales that can be envisaged as a heterogeneous and evolving whole where the individual elements - the exempla — could be played off against and compared with one another; an exemplum is never interpreted on its own, but always in the context of others' (Langlands 2015: 69). She emphasizes that exempla do not simply constitute models, or models that need adhering to, but that they function as 'sites of exemplarity', a term she borrows from the notions of 'sites of memory' (lieux de mémoire), developed in the field of Memory Studies. ${ }^{7}$ At those sites, as with myths, there is no single authoritative story of an exemplum to begin with. Instead, there is a sense of ethical flexibility and autonomy: an example needs choosing and selecting, and any implementation or imitation needs awareness and scrutiny over whether it is an appropriate example - both in its own narrative and ethical context, and in that of any recipient. Langlands develops her thinking of Roman exemplarity, as a cultural phenomenon, and she pays close attention to (Aristotelian) 'situation ethics', and to the acknowledgement of such contingency and 'situatedness' by which an exemplum generates meaning in Roman texts other than those that are most explicitly about the collection of examples (such as Valerius Maximus' Dicta et facta) — in her case Seneca and Cicero (Langlands 2011). She is also at pains to emphasize that, pedagogically, exempla function not simply as 'models', but as a first step, as creating a working template on which new iterations, reflections, and comparisons need to be built. An exemplum works precisely because it is not equally adaptable to each situation: what is appropriate to one character is not so to another, or at another time. In other words, exempla signal provisionality, and they signal awareness of conventions. One of the examples for this is Seneca's awareness, expressed in Ep. 120, that the virtues of admirable exempla are underpinned by vices, and that both require

\footnotetext{
${ }^{7}$ As for example in the volumes produced by Pierre Nora and his research group in the 1980s; Nora (1984-1992); of course, the term relies on Roman oratorical and mnemonic practices.
} 
exaggeration (Langlands 2015: 71). If exempla are 'site-specific', they inevitably take part in modes of historical understanding. They do so in the sense that they come 'earlier', but also, importantly, in the sense that they require an understanding of their situation as much as of the situation of the reader, hearer or student of an exemplum. I use the term 'situation' advisedly, instead of simply 'historical context', in order to interrupt a sense of 'context' as something that takes place only in the past or that is separable from its 'text', and that aims at completeness rather than highlighting process and protestation.

That exempla are deeply implicated in history, on a vertical as much as a horizontal axis, is clear already in antiquity. Aside from the Latin examples which Langlands cites, a good parallel source is of course Plutarch, who in his Parallel Lives habitually lets his readers participate in his biographees' own attempts at reading and at using exempla of the past in the present. Importantly, this is not simply about seeing exemplary characters witnessed in the act of themselves reading in an exemplary fashion. Often, those are attempts that underline precisely the lack of fit or emphasise the workings of exempla as implying an incomplete or injudicious transfer of meaning and fit.

A good representative example of this may be the Life of Phocion, which Plutarch pairs with the Life of Cato the Younger. That those narrative lives, or Lives in Plutarch's overall project, are paired, is itself a useful reminder that comparison itself is inherent in exemplarity. In fact, in an early section of the Life of Phocion, the act, or rather the mode and challenges of comparison are explicitly discussed — an emphasis that is echoed in the complex level of entanglement between the lives, in so far as the Life of Phocion explicitly refers to an unusual degree to the figure of Cato throughout. Both men's similarity (homoiotetas) as good men of politics, leads to a reflection on the different manifestations of bravery, wisdom, and justice in comparable men, against the same character, shape, and colour they share: 'we thus', Plutarch concludes, 'need a very fine-grained way of arguing 
(leptou logou kathaper organou) for the differentiation and establishment of differences' (Phoc. 3.4).

Phocion's case is very much portrayed as one of time, or rather his times, definitely not being amenable: it is the Athenian polity in decline, and fate or tyche in addition, that act as an impediment to his virtue. The Life itself is full of examples of untimely phenomena, such as fruit ripening out of season (and thus spoiling), or the lack of appreciation which the politically honest man meets in the declining city likened to a wound irritated by honey or an inflamed eye irritated by light (Phoc. 2.1-3). Phocion, in his combination of being principled and yet flexible, attempts to make the best of a bad situation. Cato, too, is an untimely character: but unlike Phocion he is too hard and 'unbending' (Cat. Min. 1.2), where Phocion was, by some accounts at least, arguably too flexible. Plutarch's specific account of Phocion has roused scholarly interest in so far as he seems to present a notably more positive evaluation of him and of his political decisions than he did elsewhere in his own work, especially in the Life of Demosthenes, who was Phocion's contemporary. ${ }^{8}$ Rather than noting this as an inconsistency or a reflection of different source materials available to Plutarch, though, this would fit the structures of exemplarity especially well when we understand exemplarity as a deeply situated and circumstantial invitation for reflection and action.

Just as exemplary behaviour and its success is therefore extremely situational and dependent on timing, so is exemplarity itself and the act of applying exempla, as Plutarch shows in his attention to Phocion and especially Cato as practitioners. Phocion is himself shown to imitate other characters, namely the general Chabrias under whom he serves as a young man (Phoc. 6). It is significant, though, and significant for an understanding of exemplarity and its imperfections, that the general is portrayed as someone of an uneven and

\footnotetext{
${ }^{8}$ On the discussion of this feature, see Duff (1999: 133-4), who points out Plutarch's readiness to treat different ethical dimension of a single character in different contexts.
} 
intemperate nature (physin anomalon kai akraton), on whom Phocion in turn had a beneficial effect (epanorthoumenos). Another reference point that links the particular pair of Phocion and Cato in a time of unwelcoming political circumstances, circumstances that in the end are lethal for them, is the triangulating comparison with Socrates and his death. Both Phocion and Cato profess an affinity for Plato as a teacher and thinker (as did Plutarch), even though Cato bungles the comparison he actively seeks with Socrates, reflected especially in his keen desire to emulate the philosopher and in his reading the Phaedo in preparation for his own death. Again, notably, it is actors within the Lives who themselves effect comparisons and invoke exemplarity. So does Plutarch himself, who remembers Socrates' trial and execution when he considers Phocion's own fate at the hand of the Athenians: this includes that in both cases the Athenians came to regret their decision, trying to make amends through memorialization, but also themselves in turn drawing on the comparison between Socrates and Phocion: 'What happened to Phocion reminded the Greeks again of what had happened to Socrates, in so far as this city suffered from the same mistake and misfortune' (Phoc. 38.2). This being the closing statement of the Life of Phocion, it is the mishandling and untimely use of exemplarity that marks the end of one Life and the transition to another, a transition that itself ranges across different temporal and historical moments. ${ }^{9}$ This pair of Lives is full of comment on the use of exemplarity, rhetorical or moral, but it is also a contextual study that tries to situate both characters within their own times, exploring the historical dynamic of each, and the moments at which anachronism is at work both within the two Lives as well as between them. It externalizes the inner workings of exemplarity like the

\footnotetext{
${ }^{9}$ Duff (1999: 135) points out how much this pair of lives is also marked by a pronounced lack of interest in traditional or linear chronology: it moves around between the two characters in each of the lives, before settling on a sequence of events that follows a directed life narrative.
} 
Centre Pompidou in Paris externalizes its inner structures, as Plutarch typically, exemplarily, does.

\section{Exemplarity after antiquity}

As mentioned above, a persuasive argument been made about a 'crisis of exemplarity' that comes to a head in the early modern period. ${ }^{10}$ This crisis describes a tension between rhetorical and moral expectations attached to ancient figures on the one hand and new historical understanding of those figures, in a critical and also philological vein, on the other hand, an ongoing entanglement, that is getting to feel increasingly more entangled, between forms of historical criticism and epideictic rhetoric. 'Exemplarity' becomes more difficult as historical 'unavailability' is invoked. And once textual form becomes thinkable through the question of 'forgery' vs 'authenticity', for example, then the question of decorum, and of the 'amenability' of exempla, is also thrown into new relief. And yet (and this is one of the points made clearly by Langlands), when Montaigne acknowledges that 'tout exemple cloche' — every example 'limps' or 'snags' — (Essais III, 13, in Langlands 2011: 102), this may activate a new sense of crisis, but it is by no means an alien feature of exemplarity already in antiquity: exempla appeal to similarity, and a similarity that needs working out, never resting on complete overlap. What is more, exemplarity in this sense also allows for negative responses, rejection, doubt, and dislike. And in that sense the exemplum, like the simile, also implies active choice. As the poetry scholar Stephanie Burt said, apropos simile: 'We cannot escape metaphor. [...] But we can always decide whether we will use "like": simile carries a signal of conscious choice. It shows that we know how much of language is artifice, how much we make up when we try to describe the world' (Burt 2014: 18).

\footnotetext{
${ }^{10}$ See n. 3 above; for the afterlife of Plutarch's exemplarity, and the waning scholarly interest in Plutarch, Güthenke (2018).
} 
The exemplum is thus a mode of encounter with a past that promises insight or norms beyond the particular, yet also requires selectivity; it is a mode of knowing and of organizing knowledge of the past. ${ }^{11}$ It is also a persuasive term, designed to construct a particular and particularized form of attentiveness. It is activated without implying a self-evidently or unequivocally positive template for a present moment; it is both situational and emphatically interrupting both context and a stable temporal relationship. An exemplar is not invoked as a representative cross-section of a historical point in time and space, it is thus not the object of the comprehensive, total dream of Altertumswissenschaft. It is a singular case designed to illuminate a single case, an invitation designedly to dislodge one situation for the sake of activating it in another. The exemplum can thus also challenge the logic of the pars pro toto that underlies our expectation of contextualization and exemplarity, and replace it with a logic of the pars pro parte. The exemplum, as a tool of self-positioning, insists that the past is necessary to stimulate comprehension and action in the present. But at the same time, it relishes and embraces selectivity, it suspends a fantasy of mastering complete context, it picks and chooses, programmatically. It offers a counter-weight to and interrupts the linear, progressive, transformative narratives of modern historiography and of modern Altertumswissenschaft, cutting a swathe, or so I like to think, through the stereoscopy, both explicit and tacit, of historicism and idealization that has marked modes of reading antiquity certainly in the modern period, if not well before. And in doing so, it makes sure that the difference implied in similarity matters and signifies, too.

What makes exempla special is that they break through time in an unexpected way. As such, they remind me of the counter-intuitive observations the literary critic and historian (and theorist of comparative literature) Peter Szondi made forty years ago apropos the

\footnotetext{
${ }^{11}$ This paragraph is very indebted to the collaborative thinking done in the forthcoming volume Postclassicisms, especially its section on 'Situatedness', The Postclassicisms Collective (2019).
} 
contrast of historicism and presentism (that is still very much a binary of choice in discussions of especially Classical Reception Studies now). In his Introduction to Literary Hermeneutics (1975), he highlighted a telling pattern. Trying to give an overview of the German hermeneutic tradition that was so closely connected with the development of philology as a discipline, he points out the two basic and never fully isolated tendencies of hermeneutics, going back to antiquity: on the one hand what he calls the 'historicalgrammatical', where we try to reconstruct a text or object as precisely as possible in its context; and on the other hand what he calls the 'allegorical', where we dislodge part of it and extend and interrogate its meaning for the present time. What Szondi does next is to invert an assumption about the relative distance those two approaches imply. For him, it is the historical-grammatical that actually encourages a much larger 'presencing': by trying to come as closely as possible to the 'original' in its most immediate state, despite all the acknowledgements of the pasts' foreignness; the allegorical, by contrast, is in some sense much happier to acknowledge and leave in place a certain obscurity and an unresolved past, maintaining a sense of distance of the object as a whole.

This is not about advocating a return to allegorical, or indeed exemplary, forms of readings above historical ones. Nor is it about turning back the clock or wholesale 'rescuing' earlier forms of reading. Historicism as part of Classics is, one way or another, here to stay. Instead, it is about advocating reflection sensitized to history, reflection that recognizes that ostensibly 'distanced' reading strategies ('the past is a foreign country') may have a greater tendency towards 'presencing' than strategies that seem prima facie less preoccupied with historical distance or historical context. This is a tendency towards presencing that I would understand as itself an affectively invested and deeply fraught form of 'anachronism' that seeks transhistorical forms of communion, however fugitive, while insisting on the primacy 
of historical investigation as ultimately forbidding such communion. The result is a kind of repressive — and repressed — longing for anachronism as presencing.

One of the starkest expressions of this may be Wilamowitz's famous appeal to 'blood for the ghosts' (with Wilamowitz, of course, an exemplar in his own right when it comes to perceptions of the history of classical scholarship, and to its practices). ${ }^{12}$ One of the most frequently quoted phrases of Wilamowitz, at least in the English-speaking world, it comes from a lecture he gave in Oxford, in English, in 1908:

The tradition is dead; our task is to revivify life that has passed away. We know that ghosts cannot speak until they have drunk blood; and the spirits which we invoke demand the blood of our hearts. We give it to them gladly; but if they then abide our question, something from us has entered into them; something alien, that must be cast out in the name of truth!' (Wilamowitz 1908: 25).

Wilamowitz's Herzblut emphasises the heart's desire for proximity and the reactive need to pull back in the name of Wissenschaft and science.

It is worth contrasting this attitude with that of a text which seems to be no less forthcoming about the wish to commune with the dead, namely Petrarch's 'familiar letters'. Petrarch's Familiares, or Rerum familiarium libri are a set of twenty-four books of all together 350 letters to friends, collected and reworked over many years from 1325 to 1366. Curating them into a developing collection was inspired by Petrarch's own discovery of Cicero's letters Ad familiares in 1345 as a model for communication, community, and selffashioning across space and time. The last book of the collection is made up of a series of

\footnotetext{
${ }^{12}$ For one manifestation of this exemplarity see Nimis (1984) on the 'Wilamowitz footnote' - a token reference that is much less about content than about the visibility of acknowledgement.
} 
letters composed to ancient writers. It is clear from archival sources that Petrarch would arrange his letter collections in a non-obvious and non-linear chronology, proceeding thematically as much as chronologically, rewriting, reattributing dates, sometimes changing particular names of people or places in favour of less temporally specific items, in order to recreate the exemplarity which Cicero's letters held for himself in the exemplarity of his own letters projected into the future. ${ }^{13}$ As a text genre, letters and letter collections are themselves exemplary of the trope of longing for intimacy and familiarity with the ancients. Kathy Eden has shown very persuasively that Petrarch's emphasis on 'intimacy' as a mode of approaching the classical past is a trope that reaches through the early modern well into the modern period. It shaped literary and intellectual language across Europe, and continues to shape our affective habits as scholars, extending down even into the hermeneutical traditions of the twentieth century. ${ }^{14}$

The letters to ancient writers implement the language of longing as one possible way of articulating the wish for contact across time. And yet, Petrarch's exemplarity and his anachronic gestures are also strikingly different from Wilamowitz's plea for self-imposed asceticism when weighing up immersive closeness and historical distancing. This is particularly clear in Petrarch's last letter of the series to an ancient author, the one to Homer, which is marked both as a literary conceit, but also as an expression of the challenge of overcoming a distance that is felt more intensely in Homer's case than in that of Latin authors. In its final definitive form it was headed 'To an unknown correspondent: reply to a long letter full of information addressed to himself in Homer's name and sent from the kingdom of the dead'. It remains unresolved who among Petrarch's friends and acquaintances

\footnotetext{
${ }^{13}$ Mann (2004: 24); older seminal studies on the genesis and composition of the letter collection in Rossi (1932); Billanovich (1947); for recent treatments of the epistolary Petrarch, Mazzotta (2009) and Ascoli (2015).

${ }^{14}$ Eden (2012).
} 
that correspondent was, but the points of detail raised in the letter suggest that Petrarch is responding to specific issues put forward in an earlier letter sent to him in the name of a Homeric persona. In any case, and unlike the sequence of letters simply addressed to Cicero, to Seneca, or to Horace, the full title invokes the lack of clarity surrounding Homer's origins, the absence that marks his poetic figure even more than that of the Latin writers. The question marks surrounding Homer's identity is generally reflected in the limited availability of his text to contemporary readers, but also in Petrarch's personal experience: Petrarch had, through Nicolas Sygeros, one of the Byzantine emissaries to the papal court at Avignon in 1348, received a copy of Homer in Greek, for which he thanks him in another letter included in the Familiares (XVIII.2), a letter that draws on both ancient and modern examples of good and bad gift-giving. He had also already earlier attempted to learn Greek (with the help of the Greek-speaking Calabrian scholar Leontius Pilatus), though with little satisfactory result. The absence of a complete text of Homer in Latin, and the only partial attempts at translation so far, as Petrarch points out, combined with his own lack of success in learning the language, situate Homer at a notable distance:

Franciscus Homero graie muse principi salutem. Dudum te scripto alloqui mens fuerat, et fecissem nisi quia lingue commercium non erat. Nam nec ego grecis literis discendis satis felix, et tu latinas, quibus olim per scriptores nostros adiutus uti solebas, sequentium negligentia dedicisse videbare; utrinque exclusus conticueram. Unus vir nostro te latinum seclo revehit; non hercle avidius neque diutius Ulixem tuum sua Penelope expectavit quam te ego.

Francesco sends greetings to Homer, originator of the Greek poetic muse. I had long intended to address you in writing, and would have done so, except that there was no language for communication between us. Certainly I was not successful enough in 
learning Greek, and you, though you once used to employ Latin with the aid of our writers, now seemed to have unlearned it through the indifference of their successors; so I fell silent, shut out by both circumstances. One man brought you back in Latin to our age; nor by Hercules, did his beloved Penelope wait more eagerly and longer for your Ulysses than I awaited you. ${ }^{15}$

With the mention of Penelope, it is a Homeric exemplum that is considered most appropriate to describe his own situation, and this is fully in line with Petrarch's overall investment in Homer as exemplary for the project of the collection as a whole. The Familiares are framed by two letters to his friend 'Socrates' (the Flemish humanist Ludwig van Kempen), and in the first Petrarch compares his own life largely spent in exile and wandering with that of Odysseus, exhorting his readers to do the same. ${ }^{16}$ Similarly, Petrarch decided in 1359, after reading his former teacher Leontius Pilatus's partial translation of the Odyssey into Latin, that he would arrange the letter collection into 24 books, rather than 10 or 12 , as initially planned (Mazzotta 2009: 310) — a decision that has allowed Giuseppe Mazzotta to speak of the collection as a whole as constituting an 'epistolary epic' that thematises exile, adventure, return, variety, and absence (Mazzotta 2009: 310-15). ${ }^{17}$

Between Fam I.1 and XXIV.12, Petrarch conflates his self-fashioning as both wandering Ulysses and longing Penelope, grasping after the shade of Homer, merging subject

\footnotetext{
${ }^{15}$ Fam. XXIV.12; text and translation are quoted after the recent $I$ Tatti edition of a selection of Petrarch's letters by Fantham (2017: I.478-81).

16 'Ulixeos errores erroribus meis confer: profecto, si nominis et rerum claritas una foret, nec diutius erravit ille nec latius' ('Compare Ulysses' wanderings with my own, and even if the fame of our names and circumstances were the same, he did not wander for a longer time or further afield'); Fam. I.1.21, tr. Fantham (2017: I.11).

${ }^{17}$ Notably, the 12th letter of book XXIV, to Homer, is also by a margin the longest of that final book, enacting the epic scale present within the collection.
} 
and object of desire, seeker and sought in a complex triangulation. The end of the letter to Homer, though, gives the impression of a much more clear-sighted, sceptical Penelope, rather than the anxiously waiting spouse expecting a homecoming:

Multa dixi quasi ad presentem; sed iam ab illa vehementissima imagination rediens, quam longe absis intelligo, vereorque ne tam multa in tenebris egre legas, nisi quia multa ibi etiam scripsisse te video. Eternum vale, Orpheaque et Linum et Euripidem ac reliquos comites, cum in tuam sedem veneris, salvere iube.

\author{
Apud superos, \\ medio amnium clarissimorum Padi Ticini Ardue \\ aliorumque, unde quidam Mediolanum dici volunt, \\ VII Idus Octobris anno etatis ultime MCCCLX.
}

I have said a great deal as if you were here before me, but now returning from that most passionate imagining, I realize how far away you are, and I am afraid you may be reading so long a screed with difficulty in the darkness, except that I see you have written a long letter even from there. An everlasting farewell. Bid greetings to Orpheus and Linus and Euripides and your other companions when you reach your dwelling.

Written among the living

In the midst of the most glorious rivers Po, Ticinus and Adda and others from which some want Milan to have taken its name, on October $9^{\text {th }}$ in the year 1360 of the last age. ${ }^{18}$

${ }^{18}$ Fam. XXIV.12.42-3, Fantham (2017 : II.501). 
Above and beyond the fleeing and fleeting shade of Homer, there is an assertiveness here in Petrarch to keep his correspondent at arm's length. Having engaged him, having responded, and having asked him to be amenable, he can say 'farewell forever', conscious of his position, including his exact spatial and temporal position, in the present. There is worry, and Petrarch is willing to recognize his own anxieties, but there is little nostalgia.

Besides the framing of absence and presence, the bulk of the long letter deals with Homer's place within literary genealogies and with questions of imitation, and here we find a similar tendency at the very least to supplement narratives of discontinuation or interruption with clear-eyed diagnostics of temporality. Petrarch commends Homer, from what he has been able to gather, for his comments on his own poetic predecessors and successors in search of knowledge, poetic or otherwise (like Petrarch, Homer himself is in the letter figured as a seeker after information). Petrarch also takes him to task for complaining about the imitations he has received, especially at the hand of Vergil; the Homer who wrote first to Petrarch has, we infer, expressed dissatisfaction at the extent to which Virgil has acknowledged him — in other words, the Virgil of this letter has been guilty of not marking sufficiently his own debts to his historical precedents and predecessors. Petrarch's excuse is that Virgil would have done so had he lived longer: it is not worry over decline, but an untimeliness of the most literal kind that has cut short Virgil's own acknowledgement of the workings of exemplarity.

Ultimately, Petrarch is able not just to acknowledge but to sustain distance and to draw from it in turn, much as he carefully mixes reality and fiction, absence and presence, engaging with abandon in the decorum of the conceit he created. Absence and the extent of distance are partly given and partly chosen, just as exemplarity relies on the availability of recognizable models as much as it requires site-specific choice and application. In the programmatic opening letter of the Familiares, Petrarch gives a genealogy of coming to 
compose the collection of letters in which he balances his choice for active and necessary forgetting - he was in the process of consigning letters to the fire in order to clean out with the appearance of his correspondent in front of his mind's eye, which saved the letters from destruction:

mille, vel eo amplius, seu omnis generis sparsa poemata seu familiares epystolas — non quia nichil in eis placuisset, sed quia plus negotii quam voluptatis inerat - Vulcano corrigendas tradidi. Non sine suspirio quidem — quid enim mollitiem fateri pudeat? -; sed occupato animo quamvis acri remedio succurrendum erat, et tanquam in alto pregravata navis, relevanda preciosarum etiam iactu rerum.

I gave to Vulcan for editing a thousand or more poems scattered in every genre as well as intimate letters - not that nothing in them pleased me, but because they involved more trouble than pleasure. Not without regret — why feel shame to admit weakness? But I had to ease my preoccupied spirit with some remedy however fierce, and like an overloaded ship on the high seas, I had to relieve it even by the loss of precious cargo. ${ }^{19}$

Even the affective terms of tenderness (mollitiem) and sighing (suspirio) are motivated in part by necessity and in part by choice: it remains ambiguous whether they are the result of his overbalanced and overstuffed mind and desk, or whether they indicate the feelings generated by his active choice of throwing letters and poems out. To have the choice, though, matters.

Nicholas Mann has shown that Petrarch's particular dynamic of editing and creating the Familiares is most notably on show when one considers the missive forms of the letters

${ }^{19}$ Fam. I.1.9; Fantham (2017: I.7). 
that are preserved in some cases, that is to say the copies of letters as they were actually first circulated, rather than their definitive form as included in the collection. Apropos the 'Letter to Homer', Mann describes the manuscript version of the missive: 'on the back of this letter, which had been folded in three as if to be sent, is written the address: 'Homero Meonio poete inaccessibili': to the poet Homer in deepest Lydia. The folding, the layout and even the script of the address follow closely those of Petrarch's authentic letters, and I have no doubt that this is a faithful copy of a Petrarchan autograph, which may serve to show once again the extent to which Petrarch was capable of mixing fiction and reality, and how intimate was his symbiosis with his literary forebears' (Mann 2000: 25). Grammatically, the adjective inaccessibili, 'unreachable', agrees with the dative of 'the poet Homer (Homero poete)'; in his translation, Mann implies an extension of this to Meonio, the adjective of Meonia, or Lydia, one of the reputed homelands of Homer. This works well with balancing the period of the sentence, but it glosses over how strongly it is the poet himself who is elusive. Not only is Homer from a far-away place, but Petrarch is upfront and unapologetic about Homer's own inaccessibility, about Homer being beyond reach, just as he is unapologetic about the fantasy of contact as precisely a construct and a strategy. Mazzotta has spoken of the inconsistencies, in the approach to fellow correspondents or in the varied use of style employed and explicitly highlighted by the letter-writer's persona across the Familiares as something that 'leads him to a carefully calculated writing posture', one that is '(self-consciously) ambiguous', with a 'mixture of candor, need for complicity, and careful distance' (Mazzotta 2009: 311), and I would submit that we see this reflected no less so in Petrarch's use of and attitude to exemplars and exemplarity.

\section{Sceptical exemplarity and Reception Studies}


It is inviting, and appropriate, to create a genealogy of Petrarch as precursor to a hermeneutics of longing: a longing for dialogue and for a form of transhistoricism that acknowledges historical difference, values and affirms the necessity of historicist practice, yet expresses a relationship of loss, absence, and a desire for re-establishing contact. And yet, I submit, one could apropos Petrarch also explore a genealogy of a rather more sceptical exemplarity, of transparent conceits, of a non-naïve, flexible and autonomous form of reading, an insistence on situatedness, site-specificity, and provisionality. This approach would not treat exemplarity as a threat to scientific historicism, both in its own right and as a revived reading practice. Nor would it consider its forms of iteration as something 'anachronistic' or ahistorical that would reject historical distance and historical approaches. Nor would it understand exemplarity to mean a form of normative classicism, of a return to models of imitation. Instead, it would create the opportunity to integrate the process of rhetoric back into scholarship, and historical scholarship itself into ethical reflection. If we emphasize the pointed, strategic, self-consciously controlled aspects of exemplarity as one of its inherent parts and as a prompt to reflection, to comparison, and to critical thought, then we also open up new spaces for theorizing and for enacting our own practices of reception and of the practices of reception we study. Rebecca Langlands has offered a persuasive account of exempla as a stimulus to critical and ethical thinking, as the essence of Roman reading practices already, insisting that there is no originary point of imitation or imitability that is transformed only in later iterations, but that exemplarity essentially relies on a critical, situational response. In the same way, there is no reason not to consider the appellative, critical structure of exempla for our own practices as scholars of antiquity and of its reception. In this way, we make room for the anachronic features of rhetorical and literary tropes that upset temporal stability, without having to postulate a naïve ahistoricism or an approach that is insensitive to historical distance, historical situation, or peculiarity, 
embracing the full spectrum of inaccessibility at the same time as mobilizing it for our own position vis-à-vis the past.

Such new attention to exemplarity would also bring new impulses to Classical Reception Studies, which I take to be an integral part of Classics, allowing it to cut both across terminology and as a consequence also across genres in new ways. A good amount of the vocabulary and terminology of Reception Studies as we know it derives specifically from literary studies, and it is with a view to literary and artistic examples that it has tended to maintain a dialectic of historicism and aestheticism, and a binary terminology to go with it, as a way of negotiating and emphasizing either past or present, distance or contact. ${ }^{20}$ In the terminology of Reception Studies and 'reception aesthetics' there has been an underlying reliance on the language of Gadamer's philosophical hermeneutics; and in invoking the work of especially Hans-Robert Jauss and Wolfgang Iser as exemplary thinkers, Reception Studies has relied on those who had taken and developed those hermeneutics predominantly in literary and artistic directions. As mentioned above, Kathy Eden has suggested, apropos Petrarch, that one could trace a line from Petrarch's trope of intimacy with the ancients as far as the early twentieth-century hermeneutics of Gadamer. But maybe there is an additional way to tweak the genealogy that links Petrarch with Gadamer. Why should we not try to insert into the current language of Reception Studies a sense of sceptical, situated exemplarity that can just as easily be derived from Petrarch? (And that, for added value, would infuse some scepticism to the ostensibly self-evident use of Gadamer for Reception Studies, too). To take 'exemplary reading', in its ethical, critical, rhetorical, and complex historical trajectory seriously, would mean to think about exempla in a way that does not simply put them in the same 'un-modern' category as 'imitation', two concepts ostensibly falling out of fashion and from grace after, at the latest, the Querelle des Anciens et des

\footnotetext{
${ }^{20}$ For this binary and its limitations, see Güthenke (2013).
} 
Modernes, and both of them concepts that benefit from new critical attention for acts of reading now. ${ }^{21}$ It would offer a new way also to reconsider the place and standing of sources from rhetoric, philosophy, biography, history, and historiography in Reception Studies, opening fresh perspectives on texts that themselves often have a much longer history of popular and critical engagement than their recent history and their relative neglect in mainstream Classics and Reception Studies would suggest. There is no reason why writers such as Plutarch, Xenophon, or, for that matter, Valerius Maximus should not hold and repay the attention of scholars of Reception who are keen to consider the theoretical basis and the theoretical possibilities of their own practice. These may sound, to an extent, like purely pragmatic considerations. But exemplarity is, to recall Elizabeth Bishop's words, both 'precipitate' and 'pragmatical' — it reflects and it reflects on anachronism and on ethical categories, making us decide and learn to know in each new case whether time is amenable or not.

\section{References}

A. R. Ascoli, 'Epistolary Petrarch', in A. R. Ascoli and U. Felkeid (eds), The Cambridge Companion to Petrarch (Cambridge: Cambridge University Press, 2015), pp. 120-37.

G. Billanovich, Petrarca letterato. I. Lo scrittoio del Petrarca (Rome, 1947), pp. 1-55.

E. Bishop, Poems (London: Chatto \& Windus, 2011).

C. Burrow, Imitating Authors: Plato to Futurity (Oxford: Oxford University Press, 2019).

S. Burt, "'Like": a speculative essay about poetry, simile, artificial intelligence, mourning, sex, rock and roll, grammar, romantic love, William Shakespeare, Alan Turing, Rae

${ }^{21}$ For a recent revaluation of imitation, se Burrows 2019. 
Armantrout, Nick Hornby, Walt Whitman, William Carlos Williams, Lia Purpura, and Claire Danes', The American Poetry Review, January/February (2014), pp. 17-21.

T. Duff, Plutarch's Lives: Exploring Virtue and Vice (Oxford: Oxford University Press, 1999).

K. Eden, The Renaissance Rediscovery of Intimacy (Chicago: Chicago University Press, 2012).

E. Fantham (trans.), Francesca Petrarca: Selected Letters, 2 vols. (Cambridge, MA: Harvard University Press, 2017).

S. Goldhill, 'The Limits of the Case Study: Exemplarity and the Reception of Classical Literature', New Literary History 48.3 (2017), pp. 415-35.

C. Güthenke, 'Nostalgia and Neutrality. A response to Charles Martindale', Classical Receptions Journal 5.2 (2013), pp. 238-45.

— , 'After Exemplarity: A Map of Plutarchan Scholarship', in J. North and P. Mack (eds), The Afterlife of Plutarch, BICS supplement 137 (London: Institute of Classical Studies, 2018), pp. 179-91.

—, Feeling and Classical Philology: Knowing Antiquity in German Scholarship, 17701920 (Cambridge: Cambridge University Press, 2020).

T. Hampton, Writing from History: The Rhetoric of Exemplarity in Renaissance Literature (Ithaca: Cornell University Press, 1990).

R. Koselleck, 'Historia Magistra Vitae: Über die Auflösung des Topos im Horizont neuzeitlich bewegter Geschichte', in H. Braun and M. Riedel (eds.), Natur und Geschichte: Karl Löwith zum 70. Geburtstag (Stuttgart, 1967), pp. 196-219.

R. Langlands, 'Roman Exempla and Situation Ethics: Valeruis Maximus and Cicero De Officiis', Journal of Roman Studies 101 (2011), pp. 100-22. 
— Lüdemann, Exemplarity and Singularity, pp. 68-80.

— Exemplary Ethics in Ancient Rome (Cambridge: Cambridge University Press, 2018).

M. Lowrie and S. Lüdemann (eds.), Exemplarity and Singularity: Thinking through Particulars in Philosophy, Literature, and Law (London/NY: Routledge, 2015).

N. Mann, 'From Laurel to Fig: Petrarch and the Structures of the Self', Proceedings of the British Academy 105 (2000), pp. 17-42.

G. F. Mazzotta, ‘Petrarch’s Epistolary Epic: Letters on Familiar Matters, rerum familiarum libri', in V. Kirkam and A. Maggi (eds.), Petrarch: A Critical Guide to the Complete Works (Chicago: University of Chicago Press, 2009), pp. 309-19.

S. Nimis, 'Fussnoten: das Fundament der Wissenschaft', Arethusa 17.2 (1984), pp. 105-35.

P. Nora (ed.), Les lieux de mémoire, 3 vols (Paris: Gallimard, 1984-1992).

F. Petrarch, Letters on Familiar Matters (rerum familiarium libri). Vol 3: Books XVII-XXIV, transl. A. S. Bernardo (Italica Press: New York 1985).

The Postclassicisms Collective, Postclassicisms (Chicago: University of Chicago Press, 2019).

F. Rigolot, 'The Renaissance Crisis of Exemplarity', Journal of the History of Ideas (special issue) 59.4 (1995), pp. 557-63.

V. Rossi, 'sulla formazione delle raccolte epistolary petrarchesche', Annali della Cattedra petrarchesca 3 (1932), pp. 55-73.

P. Szondi, Einführung in die literarische Hermeneutik (Frankfurt a.M.: Suhrkamp, 1975) = Introduction to Literary Hermeneutics, trans. M. Woodmansee (Cambridge: Cambridge University Press, 1995). 
U. von Wilamowitz-Moellendorff, Greek Historical Writing and Apollo, Two Lectures Delivered before the University of Oxford, June 3 and 4, 1908, translation by Gilbert Murray (Oxford University Press, 1908). 